\title{
Self-harm in children placed in a Court-Mandated Holding and Education Centre. Analysis of socio-demographic variables and influence of implementation of judicial measures
}

\author{
G García
}

Zaragoza court-mandated detention and education centre

\begin{abstract}
:
Objectives: To analyze and understand the existence of self-harming behavior in a detention centre for minors.

Methods: Review of self-harm cases detected in a population of 94 inmates in 2013.

Results: $26.5 \%$ of young offenders have conducted some form of self injury. $28 \%$ of individuals with self harming behaviors have more than 6 episodes over the period of internment. Self-beating is the most common type of self-harm performed by this group. Inmates serving sentences in the therapeutic section tend to present spillover effects in terms of self-injury.

Discussion: The population held in prison show higher percentages of self-harm than amongst the general population. The chosen type of behavior is determined by the institution. Inmates that present greater mental fragility tend to perform these behaviors and in greater number.
\end{abstract}

Key words: Prisons; Adolescent; Spain; Judicial Decisions; Aggression; Therapeutic Use; Communicable Period; Wounds and Injuries.

Text received: 11/13/2014

Text accepted: 02/08/2015

\section{INTRODUCTION}

Today's concern for self-harming behaviors among teenagers has lead researchers all over the world dedicate part of their investigation on understanding, analyzing and preventing these attitudes. Such research has been mainly conducted on standard teenage populations ${ }^{1-4}$, as well as in populations under special circumstances such as teenagers admitted to child and youth psychiatry facilities ${ }^{5}$, or imprisoned young offenders 6 .

When initiating a bibliographic reference on this issue, it is worth noting that we face the initial question of defining and identifying the concept of selfinjury; a discussion which Brown and Power assess in their work ${ }^{7}$ and which is settled by agreeing with the proposal of the ISSS (International Society for the Study of Self-injury): "the deliberate, self-inflicted destruction of body tissue without suicidal intent and for purposes not socially sanctioned". This definition is also acknowledged in this paper.

Different research conducted on this issue reveal different percentages. And so, Swadi ${ }^{1}$ concludes a prevalence of $28 \%$ of self-mutilation among New Zealander teenagers. Mikolajczak ${ }^{2}$ assessed a sample of 500 English adolescent students and concluded a prevalence of around $27 \%$ with $70 \%$ of the sample admitting that they had never had such behaviors and $3 \%$ who did not answer. For Sacarcelik ${ }^{5}$ the percentage for the average adolescent population would range between $14 \%$ and $39 \%$ and this figure would shoot up even further to $40 \%-61 \%$ among teenagers hospitalized at the department of psychiatry. Madge ${ }^{3}$ concluded that $14.6 \%$ of respondent adolescents had considered the idea of self-injury at some point but had never actually carried it out, $2.6 \%$ had been 
involved in an episode of some type of self-harming behavior and 3.2\% had presented several episodes. That study concluded too that the rate of self-harming ideas and the rate of episodes of self-harming behavior were twice as high in females as in males. For Ulloa ${ }^{4}$ self-harming behaviors among the general population are around $8 \%$, however this figure rises to between 13 and $23 \%$ when considering adolescents. As far as the imprisoned population is considered it is worth noting the study carried out by Gordon in Canadian prisons ${ }^{8}$. He identified a total of 1230 incidents among the whole imprisoned population through a 30-month period. In Spain, Mohíno ${ }^{6}$ concluded that in 1998 out of 5956 prisoners in Cataluña, 854 self-harming behaviors had been identified.

As far as the forms that self-injury takes we have also observed that there is a wide variety in the analyzed bibliography. Mikolajczak ${ }^{2}$ pointed out that over $50 \%$ include self-bruising, around $24 \%$ cutting and the rest are related to medication and drug abuse, among others. Gordon ${ }^{8}$ concluded that among the imprisoned population the most common forms of self-injury included cutting, the use of ropes and selfbruising. Yet other authors such as Manca ${ }^{9}$ point out other types of self-injury: "Most commonly self-injury includes cutting, self-burning, scarification, interfering with wound healing, self-biting and inserting objects under the skin and the nails". Other authors have also identified other behaviors such as: swallowing objects or interfering with wound healing ${ }^{1,5}$, as well as selfshooting, jumping from height, pinching, burning, biting, etc.

Through this study we intend to raise awareness of the reality of self-injury among teenagers hosted in a Reform Centre. This research is based on the hypothesis that a large number of the episodes of self-injury are not recorded, unless they entail considerable damage requiring medical care. We believe that by means of thorough care in the detection of self-injury cases and a methodological procedure of recording these episodes we will be able to identify most of these incidents, which can also be associated to a series of variables regarding genre, age, nationality and legal situation.

\section{MATERIAL AND METHODS}

\section{Population}

This study has been carried out on the population hosted in 2013 in Zaragoza's court-mandated detention and education centre. This is the only facility in the autonomous community of Aragon in which court-mandated detention measures are served for young offenders. Throughout 2013 a total of 94 young offenders were hosted in such facility. The sample of this study included a total of 25 adolescents- those who reported some form of self-injury.

\section{Methodology}

The present document is a descriptive study of sociodemographic features of the imprisoned population who has carried out some form of self-injury, including their legal situation to assess whether this plays a significant role in the development of such behavior. Therefore, the variables taken into account have been the following:

- Sociodemographic variables: genre, age and nationality.

- Legal variables: type of crime, period of imprisonment and section where the measure has been served.

Research methodology has included the collection of data based on monthly infirmary records regarding medical care susceptible of identifying self-harming behavior. Based on such records, individual inmates were identified as well as the date of the provision of medical care, to eventually access educational diaries (documents where the educational team, who shares 24 hours a day with young offenders, collect the more significant details of everyday life in morning-evening and night shifts) to analyze the day of the incident as well as three days before in case self-injury was produced days before the provision of medical care and it had gone unnoticed. The fact that such behaviors can be unnoticed is due to several reasons, including hiding self-injury, incidents happening when medical care is not provided, self-injury not requiring assistance, etc. Moreover, we have thoroughly evaluated educational diaries belonging to certain inmates who frequently presented such behaviors and who most commonly pursued no medical consultation. Finally we recorded all the cases which required medical care provided by external services (specialized and emergency medicine) throughout 2013.

The concept of "spread" included in the bibliography in the sense that such behaviours can promote or entail the imitation of the latter, was something that we were especially interested in evaluating. We have therefore classified the number of self-harming incidents according to the sections of the facility where the inmates involved were hosted. The facility counts upon four different sections: reception, closed, therapeutic and semi-open. 


\section{Statistical processing}

Statistical processing has been carried out by means of SPSS version 20.0 software. Pearson's chisquare test with significance levels of $\mathrm{p}<0.05$ were used.

\section{RESULTS}

We therefore count upon a specific population at a specific time and in a precise location susceptible of carrying out self-harming behaviors in a percentage ranged between $6 \%$ and $60 \%$ according to the available bibliography with the additional risk that these circumstances are potentially promoters of such behaviors.

\section{Number of inmates with self-harming behaviors}

Throughout 2013, 94 young offenders were admitted to the CEIMJ, with an average detention period of 162 days (the interval ranged between 3 and 365 days).

The number of self-injury incidents was 134 , which entails an average of 1.4 episodes per offender. However, by means of the aforementioned methodology we were able to identify those involved in such incidents: a total of $\mathbf{2 5}$ individuals. This implies that $\mathbf{2 6 . 5 \%}$ of young offenders hosted in CEIMJ in 2013 were involved in some type of self-injury.

We assessed a series of general demographic variables (genre, age at the time of detention and nationality) as well as detention periods and the type of crime committed by those 25 inmates.

\section{Genre}

Only one female was involved in self-mutilation. Out of 25 inmates involved in such behaviors $96 \%$ were male and $4 \%$ female.

If we consider that the rate of male inmates in 2013 was $93.7 \%$ and that of female inmates was 5.3\% we conclude that the rate of self-injury among female inmates in this facility in 2013 was $20 \%$ and that of male inmates $27 \%$.

The percentage of self-injury as far as nationality is concerned is relatively homogenous yet it is worth noting that European population almost doubles the rest of nationalities as far as these behaviors are concerned. (Table 1)

We were powerfully struck by the fact that, as far as the age is concerned, the younger the offender is the higher the rate of self-injury is, considerably dropping as age increases. (Table 2)

Statistical processing of sociodemographic variables (genre, age and nationality) revealed no significant association with self-injury by means of Pearson's chi-square test ( $\mathrm{p}>0.05)$.

As far as the type of crime committed, table 3 displays the main reasons for detention. We can see that for three of them the percentage is $50 \%$ and that the commission of such crimes implicitly entails an aggressive attitude towards others. (Table 3 )

In regard to the analysis of self-harming behaviors, we have observed that $50 \%$ of inmates were only involved in one episode, whereas $20 \%$ had been involved in between 2 and 5 incidents and the rest $(28 \%)$ in six or more. (Figure1)

Statistical processing, as for demographic variables, showed no significant association between the type of crime committed and self-injury.

Table 4 displays the distribution of self-injury incidents according to the section where those involved were hosted.

With reference to the high number of self-injury episodes identified in the therapeutic section we show the distribution of such incidents throughout the year. (Table 5)

Five forms of self-injury have been identified at CEIMJ: self-bruising, punctures, cutting, jumping from height and choking. When compared with the rest of bibliography we observe that our results are in line with other publications except for the fact that adolescents in a detention facility do not have at their disposal other resources that can be available in an open environment. Therefore, self-injury is influenced by restriction and limited or null access to certain objects: there is no access to rigid sharp objects, belts, ropes, laces and other similar things, access to high locations is restricted yet adolescents are surrounded by a facility built on concrete and steel. (Figure 2)

Out of 134 self-harming episodes, 21 (15\%) required external medical care, by means of emergency or specialized care. More specifically 19 cases needed Traumatology specialized care, and 2 required the intervention of Psychiatry services, one of them needing hospitalization in that section.

\section{DISCUSSION}

The firs relevant information that we must underline is the high number of self-injury episodes recorded at CEIMJ, a total of 134 as opposed to 854 recorded episodes in 1998 among an impri- 
soned population of 5956 inmates or as opposed to 71 in the same year in a Young Offender Detention Facility in Barcelona ${ }^{6}$. As far as this same issue is concerned, the Correctional Service Canada recorded 1230 self-injury episodes throughout a 29 month period in the total imprisoned population of Canada. We believe that this is due to a more precise method capable of better detecting this type of behaviors together with a professional team concerned and aware of the importance of detecting them rather than believing that CEIMJ is a facility where selfinjury is more common or that by coincidence, in the period chosen a series of circumstances have converged in a raised propensity to self-injury. Therefore, Canadian research by the Correctional Service Canada and several studies conducted in Spain ${ }^{6}$ only detect those episodes which entail relevant medical care, and are unable to record unmet episodes and attempts interrupted before being fully carried out, which are also considered a form of self-injury by the bibliography on the issue

As far as the percentage of detained population involved in self-injury is concerned, we cannot consider a clear reference but we can agree on the fact that the percentage of $26.5 \%$ recorded at CEIMJ would be in line with the figures concluded by Swadi ${ }^{1-2,5}$ and beyond those concluded by Magde ${ }^{3}$ and Ulloa ${ }^{4}$.

With reference to general sociodemographic variables it is worth noting that the variable genre should not be considered since the population under study, despite being the total of that hosted during the study period, is still insufficient to conclude reliable data. Anyway, and in line with what we have observed, we believe that most probably self-injury among young female offenders is significantly lower than among male offenders. As far as nationality is concerned, there is certain homogeneity regarding the rates of self-injury, which are close to the general mean. It

Table 1: Nationality

\begin{tabular}{lcccc}
\hline Nationality & $\begin{array}{c}\text { Number of } \\
\text { offenders per } \\
\text { nationality }\end{array}$ & $\begin{array}{c}\text { General } \\
\text { Distribution }\end{array}$ & $\begin{array}{c}\text { Number of offenders } \\
\text { with self-injury } \\
\text { behaviors per nationality }\end{array}$ & $\begin{array}{c}\text { Distribution of self-injury } \\
\text { population with regard to } \\
\text { nationality }\end{array}$ \\
\hline Spanish & 40 & $42.5 \%$ & 9 & $22.5 \%$ \\
\hline American & 27 & $28.7 \%$ & 8 & $29.6 \%$ \\
\hline Moroccan & 18 & $19 \%$ & 5 & $27.7 \%$ \\
\hline European & 7 & $7.8 \%$ & 3 & $42.8 \%$ \\
\hline Other & 2 & $2 \%$ & 0 & $0 \%$ \\
\hline
\end{tabular}

Table 2: Age

\begin{tabular}{ccccc}
\hline Age & $\begin{array}{c}\text { Number of general } \\
\text { population }\end{array}$ & $\begin{array}{c}\text { \% of general } \\
\text { population }\end{array}$ & $\begin{array}{c}\text { Number of offenders with } \\
\text { self-injury behaviors }\end{array}$ & $\begin{array}{c}\text { \% of self-injury population with } \\
\text { regard to age rank }\end{array}$ \\
\hline 15 years old & 6 & 6.3 & 3 & 50 \\
\hline 16 years old & 19 & 20.2 & 7 & 36.8 \\
\hline 17 years old & 33 & 35.1 & 5 & 27.7 \\
\hline+18 years old & 36 & 38.4 & & 13.8 \\
\hline
\end{tabular}

Table 3: Types of crimes

\begin{tabular}{lcccc}
\hline \multicolumn{1}{c}{ Crime } & $\begin{array}{c}\text { Number } \\
\text { of general } \\
\text { population }\end{array}$ & $\begin{array}{c}\text { \% of general } \\
\text { population }\end{array}$ & $\begin{array}{c}\text { Number of offenders } \\
\text { with self-injury } \\
\text { behaviors }\end{array}$ & $\begin{array}{c}\text { \% of self-injury } \\
\text { population with regard } \\
\text { to crime }\end{array}$ \\
\hline Homicide & 2 & 2.1 & 0 & 0 \\
\hline Attempted homicide & 2 & 2.1 & 1 & 50 \\
\hline Sexual aggression & 4 & 4.2 & 2 & 50 \\
\hline Violent robberies & 43 & 45.7 & 10 & 23.2 \\
\hline Other robberies & 13 & 13.8 & 2 & 37.5 \\
\hline Breach of probation measure & 8 & 8.5 & 3 & 50 \\
\hline Domestic violence & 6 & 7.7 & 3 & 26.6 \\
\hline Other crimes & 15 & 15.9 & & \\
\hline
\end{tabular}


Figure 1: Percentage of offenders with regard to self-injury episodes
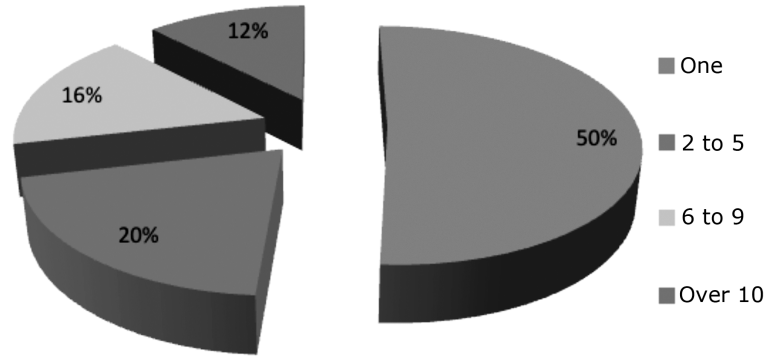

is worth outstanding the number of self-injury among European offenders, more specifically those from Romania, in which the rate is as twice as high as in the rest, a fact that could be eventually assessed. The most significant variable though has been age. As it has been stated previously the younger the offender is the higher the rate of self-injury is. This leads us to believe that adaptive skills in younger offenders are less developed yet we have not fully assessed the significance of this fact and we only propose as a hypothesis for further investigation.

Tabla 4. Autolesiones por sección de residencia.

\begin{tabular}{lccc}
\hline \multicolumn{1}{c}{ Section } & $\begin{array}{c}\text { Number of } \\
\text { self-injury episodes }\end{array}$ & Percentage & $\begin{array}{c}\text { Number of } \\
\text { inmates }\end{array}$ \\
\hline Reception & 7 & $5.7 \%$ & 3 \\
\hline Closed & 24 & $17.9 \%$ & 9 \\
\hline Semi-open & 10 & $7.4 \%$ & 5 \\
\hline Therapeutic & 93 & $69 \%$ & 8 \\
\hline
\end{tabular}

With reference to legal variables, the main crime committed tends to imply that there may be some relationship with some of the more violent crimes among young offenders who are involved in self-har-
Figure 2: Forms of self-injury

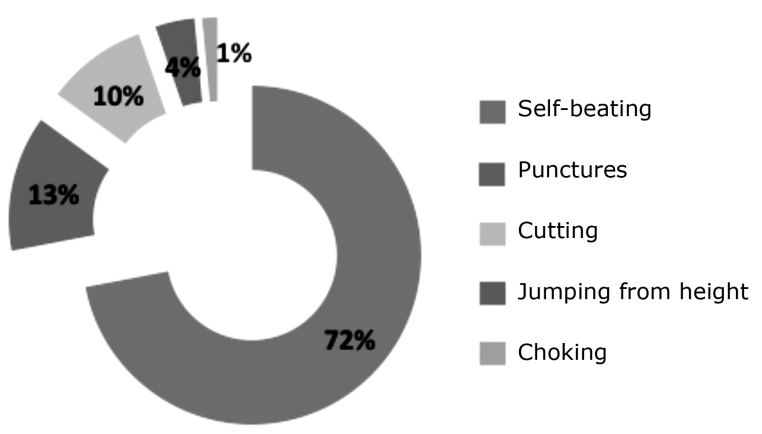

ming behaviors. However this is inconclusive if other variables are not considered (period of imprisonment, period of the measure imposed, and legal situation, among others).

Figure 1 shows how at least half of the offenders involved in self-injury behaviors repeat at least once such episodes during their detention. The fact that $12 \%$ do so ten times or more is of special concern. We can therefore consider that there is a considerable range of population who are involved in this type of behaviors at specific times, almost occasionally, as opposed to a very limited group where self-injury is a common behavior, as alarming as it may be for professionals dealing with them. We have not assessed the reasons or significance of such behavior yet we have further evaluated observable elements involved in repeated self-injury. This is why we classified self-injury episodes according to the sections where those involved were hosted as well as the variable of time (Tables 4 and 5). We were able to observe that most of the episodes converged in the therapeutic section. Young offenders are distributed in the facility according to their legal regimen, except for an adaptation period when all are hosted in the reception sec-

Tabla 5. Distribución de las autolesiones en la sección terapéutica desarrollada en el tiempo.

\begin{tabular}{|c|c|c|c|c|c|c|c|c|c|c|c|c|}
\hline INDIVIDUO & ENE & FEB & MAR & $\mathrm{ABR}$ & MAY & JUN & JUL & $\mathrm{AGO}$ & SEP & OCT & $\mathrm{NOV}$ & DIC \\
\hline $\mathrm{A}$ & & & & & & 5 & 4 & 2 & 2 & & & \\
\hline $\mathrm{B}$ & & & & & & & & & 1 & & & \\
\hline $\mathrm{C}$ & 1 & & 1 & 3 & 1 & 5 & 6 & 4 & 3 & 2 & & \\
\hline $\mathrm{D}$ & & & & & & & & 1 & & & & \\
\hline $\mathrm{E}$ & & & & & & 1 & 4 & 1 & 1 & & & \\
\hline $\mathrm{F}$ & & & 1 & & & & & & & & & \\
\hline G & & & 1 & 1 & 1 & 6 & 5 & 4 & & & & \\
\hline $\mathrm{H}$ & 1 & & 1 & 3 & 2 & 5 & 7 & 5 & 1 & & & 1 \\
\hline TOTAL & 2 & & 4 & 7 & 4 & 22 & 26 & 17 & 8 & 2 & & 1 \\
\hline
\end{tabular}


tion aimed at bringing offenders and the institution together. The time spent on that section varies according to offender features and the adaptation process. This analysis reflected that $69 \%$ of self-injury episodes corresponded to the therapeutic section. This can be in line with the profile of young offenders hosted in that section whose need for intervention goes beyond the educational and reaches the therapeutic level. Young offenders hosted in this section have already accessed the mental health and drug abuse network at some point, a fact that would support the existence of an association between mental disorders and self-injury. Last it is worth highlighting the concept of spread that some authors consider, in the sense that self-injury can be emulated by others when it is recognized. We observed that $69 \%$ of all self-harming episodes carried out in the therapeutic section happened in a 90 day period when six offenders involved in such behaviors coincided.

\section{ACKNOWLEDGEMENTS}

We want to express our gratitude to the disinterested collaboration of CEIMJ governing bodies from the Government of Aragon as well as to the staff of the Fundación de Atención Integral Al Menor (FAIM) (Children and Youth Comprehensive Care Association) and especially to all the inmates of CEIMJ in 2013.

\section{CORRESPONDENCE}

G García

Centro de Educación e Internamiento por Medida

Judicial de Zaragoza. (Zaragoza court-mandated detention and education centre)

Email: gonzalog@unizar.es

\section{BIBLIOGRAPHIC REFERENCES}

1. Swadi H. Mental health care Self-mutilation among adolescents and youth: Some clinical perspectives. Nzfp. 2004; 31: 374-7.

2. Mikolajczak M, Petrides K, Hurry J. Adolescents choosing self-harm as an emotion regulation strategy: The protective role of trait emotional intelligence. Rev. British Journal of Clinical Psychology. British Journal of Clinical Psychology. 2009; 48: 181-93.

3. Madge N, Hawton K, Mc Mahon E, Corcoran P, De Leo D, De Wilde E, et all. Psychological characteristics, stressful life events and deliberate self-harm: findings from the Child \& Adolescent Self-harm in Europe (CASE) Study. Eur Child Adolesc Psychiatry. Eur Child Adolesc Psychiatry. 2011; 20: 499-508.

4. Ulloa R, Contreras C, Paniagua K, Figueroa G. Frecuencia de autolesiones y características clínicas asociadas en adolescentes que acudieron a un hospital psiquiátrico infantil. Rev. Salud Mental. 2013; 36: 417-20.

5. Sacarcelik G, Türkcan A, Güveli H, Yesilbas D. The prevalence of deliberate self-harm behavior and its association with sociodemographic features in patients referred to secondary care psychiatric clinic for adolescents and young adults. The journal of psychiatry and neurological sciences Dusunen Adam. 2011; 24: 253-64.

6. Mohíno S, Ortega Planchat L, Dolado J, Martí G, Cuquerella A. Diferencias clínicas y psicosociales entre jóvenes reclusos con episodios de autolesiones. Revista Española de Sanidad Penitenciaria. 2002; 4: 78-83.

7. Brown J, Power S. L'automutilation : analyse documentaire et répercussions sur les services correctionnels. Ottawa: Service correctionnel du Canada; 2010.

8. Gordon, A. Incidents d'automutilation survenus dans les établissements du SCC sur une période de trente mois. Service correctionnel du Canada. Canada. Ed: SCS; 2010.

9. Manca M. Agresiones al cuerpo en la adolescencia: ¿ ¿redefinición de los límites del cuerpo o desafío evolutivo? Psicoanálisis. 2011; 33: 77-88. 